\title{
Rationale for Feminist Bibliography ${ }^{1}$
}

\author{
Kate Ozment
}

\begin{abstract}
This essay posits a framework of shared identity and practice for feminist bibliographers, book historians, and textual scholars. Feminist bibliography is positioned as the use of bibliographic methodologies to revise how book history and related fields categorize and analyze women's texts and labor. The opening section of the essay quantitatively analyzes book history companions, readers, and introductions to establish a baseline for how the field functions as a practice and discourse. The second section then analyzes the version of bibliography that has been canonized in book history, identifies how book history has explicitly favored a version of bibliography that is antagonistic to feminist work, and proposes a feminist narrative of bibliography that can and should be incorporated as the foundation for studies of the material book. The last section puts a feminist framework into practice and searches for women's contributions to bibliographic labor in the Anglo-American world. It offers a new set of founders in bibliography and challenges contemporary bibliographers and book historians to re-evaluate on whom we place importance, how we define interpretive scholarship, and how we construct our discourse.
\end{abstract}

\section{$\mathrm{I}_{\mathrm{N}}$} N i998, Leslie Howsam published an article in SHARP News titled "In My View: Women and Book History" that, perhaps for the first time, began to think about how women's studies and studies of the book engage on a theoretical level. While Howsam elsewhere defines book history as the intersection of bibliography, literary studies, and history (2006,

1. This project was partially funded through the Newberry Library's Charles Montgomery Gray Fellowship and Texas A\&M's Beth Qualls Endowed Fellowship. My thanks to Thad Bowerman, Flo Davies, Margaret J.M. Ezell, and Maura Ives for feedback on earlier drafts. An early version of this work was first presented at the American Society for Eighteenth-Century Studies conference, and I am grateful to the audience for insightful comments and to the women's caucus for honoring it with the Catherine Macauley Graduate Student Prize. Research was completed at Princeton Rare Books and Special Collections, the Morgan Library, and the Grolier Club. My particular thanks to Meghan Constantinou, Christine Nelson, and Sal Robinson for their generosity and expertise. 
4), this earlier essay offers several points forward and conflicts with a gendered approach to histories of the book. Here, she returns to foundational articles on communication circuits from Robert Darnton (1984) and Thomas R. Adams and Nicolas Barker (2001) to argue that by neglecting to consider gender these models are erroneously defaulted male. In reality "women can be identified at every node in the cycle and at all periods in history", and assuming men control the production and dissemination of books is both ahistorical and limits the discussion of gender and production (Howsam 1998, 1).

Since the 1990s, scholarship at the intersection of women's studies and book history has flourished, but the history of the book is still largely defined as a male homosocial environment where female figures are briefly mentioned on the margins of textual production or invisible altogether. When Howsam concluded that "For the most part, what [Lucien] Febvre and [Henri-Jean] Martin called 'the little world of the book' has been a male domain" $(1998,1)$, she was not only describing the state of the field, but also touching on two important values of book history scholarship. First, experiences of book production that are given significance tend to be male. The categories we focus on - booksellers, printers, and public authors - are overwhelmingly, though not exclusively, male at most points in history before the late eighteenth century. Consequently, most prominent histories pull from the types of evidence that are more likely to be preserved for or accessed by male historical subjects: papers in archives, records in institutions, and print publications. Secondly, the way researchers have defined the world of the book builds from a narrow set of scholarly texts that also skew male in their subjects: Darnton (1984), Martin and Febvre (2010), Roger Chartier (1989), and D. F. McKenzie (2002) have contributed significantly to the growth of book history as a distinct field, but their subjects are overwhelmingly white men. While the history of the book is a capacious field in practice, in self-definition it grows from limited source materials and inquiries that impact how non-canonical experiences are analyzed and valued. The "male domain" of the world of the book creates homogeneity where gender is not a factor because there is little sexual difference against which male authorship and production are defined; the same could be said of the whiteness of our core subjects, especially those within the early British tradition from which much book history scholarship grows. This narrowed identity creates a discourse where standards are universally applied that in reality are neither prepared nor equipped to analyze the experiences of historical subjects, books, and texts that fall outside a distinct set of parameters. 
This article addresses the gap between practice and identity, between how current book history scholarship embraces diverse methodologies and subjects but must do so by remediating a bibliographical history and an inheritance that limits the efficacy of key philosophies and approaches. I argue that a more intentional remediation is needed, one that explicitly gathers feminist methodologies to intervene in the genderless inheritance of bibliography in book history and revise it to foster rather than inhibit feminist scholarship. I label these practices feminist bibliography, defined as the use of bibliographic methodologies to revise how book history and related fields categorize and analyze women's texts and labor. But this article does not position itself as the invention of a discourse. Foundational work from Howsam (1998), Michelle Levy (2014), and Sarah Werner (2018) has already begun to theorize new intersections of feminism and studies of the material book, and as the rich historiography of feminist bibliography in the following pages will indicate, this tradition is long-lived. My argument provides instead the rationale for giving historical and existing practices a name, a "corporeal reality" that also "lends language to the work" many scholars are already doing. ${ }^{2}$ Feminist bibliography is philosophy and method. It promotes continuing work on women's lives and labor by providing tools for feminist scholars to use in their work, while simultaneously building a framework that allows such work to flourish.

First, I analyze existing bibliographic and book history scholarship to create an outline of how book history defines itself. In addition to the key texts identified above, most of these meta-level articles are articulated and reproduced in readers, introductions, and companions. Using these materials to take a measure of the field, my survey tracks which articles are anthologized and what subjects are indexed to get a fuller picture of what factors are valued. The results are illustrative: most items are overwhelmingly white and male with a distinct Anglo-American bias. The narrowness of this sample size is contrasted against greater possibilities using data mined from the Women in Book History Bibliography, a resource that has tracked more than 1,550 sources on women's engagement with textual production. The second section of my "Rationale" addresses the reasoning for this gap by tracing the historiography of book history as these texts describe it, a significant part of which grows out of Anglo-American bibliography. I provide contextualization for the wider fields from which these narrowed discourses grow and argue that value for and interest in women's

2. See Gallon 2016 for a rationale for black digital humanities; Gallon's essay is philosophically akin to what I propose here. 
labor in textual production has been an essential aspect of bibliographic scholarship. It is the canonization of only one part of bibliography that has led to book history's emphasis on genderless analysis. Lastly, I trace a narrative of twentieth-century women bibliographers and their labor as a new version of book history's origins that creates roots and traditions from which a gendered discourse of book history can draw.

Throughout, I argue that a philosophical revision of bibliographic methods promotes continued work on women's writing and labor in book history, my primary interest, and interrelated fields like textual studies and digital humanities. A feminist scholar will place significance on variances, oddities, and norms that another scholar might not, and this article suggests alternatives for how tools, resources, and lists might be designed to specifically promote work on women and other figures in minority categories of identity and production.

\section{Book History's Values: A Quantitative Analysis}

This section opens with a question: what does book history value?

There are methodological answers to this question that are relatively uncontroversial. Book history is an object-oriented field which grew out of the analysis of "the material object and its production and reception, rather than solely [of] [. . . its contents" (Fin Kelstein and McCleery 2012, 11). In this focus, book history relies on bibliographic methodologies for the analysis of physical books, as the disciplinary precedent for book history is historical bibliography. ${ }^{3}$ The intended result of an object-oriented approach is that it puts the book and its process center stage, and in doing so links the cross-disciplinary interests of history, library sciences, and literary studies that approach the book as a cultural object. Beyond methodology, book history's values can be defined in what kinds of books and processes tend to capture our attention and what categories of subjects and experiences drive our analysis and provide our samples. To take a measure of this more subjective value, I turn to texts that attempt to define the field or are representative venues for work in this area. Companions and introductions trace the field's self-definition when the audience is imagined to be new scholars or disciplinary visitors. Readers point to what is considered essential when scholars are forced to distill down to the basics, and they are an effective means of assessing book history's core values and texts.

3. For an outline of historical bibliography, see Аввотt and Williams 2009; see also Suarez and Woudhuysen 2010. 
Book history companions, introductions, and readers comprise $625 \mathrm{sec}-$ tions across 22 volumes, all published in the last 20 years. To account for the 625 sections, all authored sections were counted, including subsections of larger chapters that had individual authors attached. General introductions were omitted along with appendixes and other paratexts. The earliest example is the Cambridge History of the Book in Britain published in 1999, and the most recent is the 2017 Broadview Introduction to Book History. There has been a substantial increase in these publications, with 17 out of the 22 volumes, or $77 \%$, published from 2007-2017. Ten volumes are general-interest book history texts that span major publishers: Wiley-Blackwell (2009), Oxford (2010; 2013), Cambridge (2014), both editions of the Routledge introductions and readers (2006; 2012), and the Broadview introduction and reader $(2014 ; 2017)$. These are supplemented by series that focus on America and Britain. The former, from North Carolina, is five volumes (2014), and the latter, from Cambridge, is six volumes (1999-2009).

I first tracked how many women-presenting authors were included in or edited these volumes. Women-presenting authors and editors are globally in the minority, but a few volumes approach gender parity for contributors. Perhaps tellingly, volumes edited by a woman were more likely to have a higher proportion of women-presenting contributors. My content analysis focused initially on surface-reading section titles to look for identifying information about what kinds of subjects the author focused on - subjects that presented as male or female or books and processes where the gender presentation of the creator could be identified. Out of 625 sections, there are a total of 12 where the title indicates that the section explicitly covers women. Indicators included signaling language like "gender" or "women", a woman's name, or the title of a book written by a woman. ${ }^{4}$ When the historical subject or labor is mentioned, such as the publisher or bookbinder, they are twice as likely to be male: 25 section titles indicate the subject is male or the case study is a man's labor. From titles alone, then, about $94 \%$ of chapters do not indicate the gender of the subject, nor the presence of women's labor or writing.

On the surface, it is logical that such an overwhelming majority of section titles do not explicitly refer to gender, a result of what David Finkelstein and Alistair McCleery (2012) have articulated about book history's focus on materials and processes over contents. Metal type and wooden presses tend to not be understood as gendered objects. However, my surface-level

4. The field of gender studies is not synonymous with women, but I found no examples of gendered book history studies that were about men. 
study indicates that an emphasis on processes and objects may obscure the human hands that perform and create them.

Behind the $94 \%$ of chapters where the gender of the subjects or labor is not marked are several key indications about what book history values. The majority of companions and readers divide their chapters and sections into three approaches: kinds of books, methods of production, and reading and literacy: that is, objects for study, ways of making them, and ways of interacting with them. The massive two-volume Oxford companion (2010) dedicates more than half of its length to term definitions and encyclopedia entries that encompass these three areas. Across all editions, chapters are organized around kinds of books, including legal, liturgical, religious, literary, and medicinal. Sometimes specific parts of the material book are explained, with volumes featuring sections on illustrations, paratexts, bindings, and typefaces. These approaches occasionally interact with the members of the trade who were responsible, blending a study of form with process; almost universally the examples are men. Rarely are there extended case studies of librarians, authors, printers, or other human figures, but they do exist. Most volumes will offer at least one case study of a print shop, collector, or author, using a figure like John Donne to detail manuscript circulation or Paradise Lost and Shakespeare's works to explore the machinations of the book trade. Largely, though, content in companions and introductions do not indicate from whom the objects of study originated.

When one skims the tables of contents for these volumes, they seem almost raceless and genderless, and indeed occasionally human-less. Chapters carry titles like "Bookbinding" or "Library Catalogues and Indexes", language that while specific in its focus on process or tool implies a universality in its ability to be applied to large systems or objects. Systematically examining these chapters' content uncovers that the subjects are not, in fact, universal at all but are particular in ways that have not been fully explored and have led to a limited approach to book history scholarship.

To get a more precise account of what actually happens within the chapters, I analyzed the indexes. There are limits to this kind of analysis, as with surface-level reading of section titles, but the results are again illustrative. ${ }^{5}$ When human subjects are mentioned in the indexes, they are male

5. Indexing is as human an operation as any other part of the authorship process, and there could be more beneath the surface of these texts than is evident by only looking at paratexts. A future project could include OCR and full-text 
with an overwhelming frequency. Several indexes run as low as $1.5-2 \%$ for entries that are identifiably female. None exceed $8 \%$. Only a few include an additional entry for "women" or "gender" that allows scholars interested in women's work to find examples in the volume. In a perhaps not that surprising trend, most index entries on women are within sections explicitly titled as about women, the 12 sections that comprise $1.96 \%$ of the total. There are a few exceptions from unsurprising sources, such as scholars who routinely work on women's writing and labor. Margaret J.M. Ezell's chapter on "Handwriting and the Book" in th Cambridge handbook (2014) has a generically titled chapter, but Ezell includes multiple women alongside men in her analysis. This choice is atypical.

While titles like "Liturgical Books" intend to convey the history and production of a genre, what is actually being conveyed is the history of men and their books. In this example, which is from the first volume of the Cambridge History of the Book in Britain (2011), the author limits the discussion to monastic books and their male makers and readers. It is a descriptive and thorough history of monastic liturgical books, but because it lacks any mention of convents and the female scribes and illuminators who also worked on and read such books it is not a general history of "Liturgical Books". As part of an alternative history, Marilyn Dunn (2013) details how women in convents also created books of hours and liturgical books, including acting as scribes and illuminators. And this history has been long-lived. Historians like George Haven Putnam (1896) have long detailed the role of nuns in scriptoriums in England and the relationship of female education and religious life. Despite what the Cambridge chapter suggests, women and nuns certainly did make and consume liturgical books. This chapter is not particularly egregious and far from the only place where monks are featured rather than nuns. I use this as an illuminating example, one chosen from many possibilities, of a trend in the generalized language of $94 \%$ of book history companions that normalizes the history of men as a general history. Although issues of race fall outside the scope of the analysis I performed for this article, it is also true that the vast majority of the cited subjects are white. Sources by and about people of color play a much larger role in American book history scholarship than British, which mirrors the gen-

searches, which would give a more accurate picture of the subjects and themes encompassed. 
eral lack of literary subjects of color before Olaudah Equiano and Phyllis Wheatley. ${ }^{6}$

Even this surface-level analysis reveals several significant trends in book history scholarship as it is defined and anthologized. Unless the title explicitly states that the subject is about women, the contents are overwhelmingly about men. This is challenging for scholars looking for examinations of women's contributions to the world of the book, as we often find our interests are not reflected in most scholarship. Gender can be a significant influence on how historical subjects realize economic opportunities, so male experiences do not always reliably map onto female subjects. While it is true that women are in the minority in some forms such as Stationer's Company records in England, the less than 2\% of chapters that do exist on women do not reflect historical reality when one considers the many ways women interacted with the world of books. Looking only at the broad Early Modern period in England, where I specialize, recovery work from Maureen Bell (2014) and Paula McDowell (1998) has brought dozens of examples to light about women's labor in the book trades, and Helen Smith (2012) and Lisa Maruca (2007) have argued persuasively about how book production is itself a gendered process. Beyond the book trade in England, the paucity of chapters from companions on women is in stark contrast to the wealth of information that is actually available, especially when one considers the breadth offered from Colonial America's early presses to the Victorians' mass production to modernist feminist presses.

The Women in Book History Bibliography offers a useful foil to the field as generally represented. Launched in 2016, the open-access database is edited by myself and Cait Coker and logs secondary sources as they intersect with women's labor and material culture. Currently, the WBHB has 1,550 sources logged that range from antiquity to the present day, covering dozens of countries and languages. The database allows the user to filter by field, and it is easy to see with these tools how much is missing from the general chapter titles listed above. "Book Trades" features about 440 sources, "Reading" another approximately 230 sources, and "Manuscript and Letters" features 110 sources. While the WBHB cannot be considered an authoritative account of all work in the field, the large number of available sources for just these three subjects indicates that this work is without question here. It is just not being cited, not being considered as a necessary piece of the larger picture when the field is generalized into processes and

6. Necessary complications to this trend in England include work by Hall (1995), OnYeKa (2013), and GiKandi (2015). 
objects. The WBHB has done the initial work of making this scholarship visible, but the theoretical and subjective values that have kept it on the sidelines still must be addressed.

\section{Book Historiography: Book History's Bibliographic Inheritance}

It seems clear that the values of bibliographic and book history scholarship do not explicitly align with feminist efforts. The larger question, however, is why this is the case. Here I argue that the answer lies in the intertwining of philosophy and bibliography in book history; that is, I suggest that book history inherited a discourse where gender is not central from bibliographers and journals like Papers of the Bibliographical Society of America and The Library. This discourse is positioned as book history's origin story - the debates among D. F. McKenzie, G. Thomas Tanselle, and Jerome McGann that focused on the bibliographical concerns of textual editing and authorship. Like most stories, however, it is a mixture of fact and the impulses of practitioners that sought to establish their roots in work that represented their interests in a white, male, print history. This section briefly sketches this origin story and then makes space for feminist critique, allowing feminist bibliographers to find roots for their own origins and interests.

Spanning from the 1970s through the 1990s, the important and often generative debates from Tanselle, McGann, and McKenzie continue to influence how critical editions are prepared and are widely cited in book history, literary studies, history, and digital humanities. Tanselle and McGann were examining how to produce an edition of a literary text, and the source of their disagreements was where to place meaning and define authority: on the author's intentions or on the reader's interpretation. Tanselle focused on authorial intent in textual editing, pulling from the Greg-Bowers school of New Bibliography that grew from the early- and mid-twentieth century. ${ }^{7}$ Tanselle, a student of Fredson Bowers, argued that the author's intentions were what should be paramount when preparing a scholarly edition of a text. To find an author's intent meant to consider "the intention of the author to have particular words and marks of punctuation constitute his text and the intention that such a text carry a particular

7. For a good overview of New Bibliography and the Greg-Bowers school of thought, see Greetham 1994. 
meaning or meanings" $(1991,41)$. When it was not possible for the editor to make these conclusions definitively, "his judgment about each element will ultimately rest on his interpretation of the author's intended meaning as he discovers it in the whole of the text itself" $(1991,44)$. Through a series of articles and books, Tanselle theorized the minutiae of how this editorial practice would function, at times using his work on Herman Melville as a testing ground.

Tanselle's philosophy of authority was eventually opposed by another philosophy that argued that authority should not rest singularly with the author's intentions but plurally with those who produced the text printed onto the material object. Prompting this theoretical shift was a redefinition of the author proposed by Roland Barthes (1977) and Michel Foucault (1977). Rather than the point of primary authority, the author became a function, the creator of a work that was passed into the hands of readers, who were in turn the producers of meaning. Literary scholars began to focus on interpretation, a reader-centered activity. It was a radical inversion of the existing hierarchy, and editors investigated what was the job of the textual editor when the author is supplanted or challenged by the reader's importance in creating meaning.

McGann's work was foundational in the reimagining the site(s) of textual authority. The singular author, he argued, was an anachronistic figure inherited from the Romantic poets who imagined themselves as solitary geniuses and producers of text (1985). Other forms of authorship, especially those practiced in the Renaissance, were social productions, the result of the input and influence of multiple entities. His "socialized concept of authorship and textual authority" was an attempt to correct these anachronistic definitions of authorship and restore authority to "the dynamic social relations which always exist in literary production” $(1983,8)$. McGann's contributions expanded beyond textual criticism into other aspects of bibliography, especially historical bibliography. Working within this field, McKenzie furthered the concept of the social text to a discipline: the sociology of the text. He argued that this new discourse

directs us to consider the human motives and interactions which texts involve at every stage of their production, transmission, and consumption. It alerts us to the roles of institutions, and their own complex structures, in affecting the forms of social discourse, past and present. Those are the realities which bibliographers and textual critics as such have, until very recently, either neglected or, by defining them as strictly non- 
bibliographical, have felt unable to denominate, logically and coherently, as central to what we do.

In prompting a consideration of the social production of texts, McGann and McKenzie played a crucial part, the narrative goes, in articulating what would become book history.

The thread of bibliography established by these three scholars is articulated as part of the "grounding disciplines" that "remain crucial scholarly components" of book history (RAVEN 2018, 15). Book history's reliance on this thread is abundantly clear in the analysis of companions and readers. Every general book history companion, including Cambridge, Oxford, Wiley-Blackwell, and Routledge, begins at this moment. Both the Broadview and Routledge readers include articles from these scholars. Even other related books follow this pattern, such as Howsam's Old Books and New Histories (2006), aspects of An Introduction to Bibliographical and Textual Studies, edited by Craig S. Abbott and William Proctor (2009), and James Raven's What is the History of the Book (2018). It has, effectively, become canon.

Canons help give shape and energy to rapidly establishing fields, which book history no doubt was during the decades in which these articles were written. But canons, as feminist scholars have long argued, also work to limit and distance, especially when they are not fully understood to be constructions but are presented as objective assessments of what is "good" or "valuable" in a discipline. It is not this section's goal to diminish this debate's importance and influence, but to analyze how the over-reliance on this one thread of bibliography as the theoretical framework for most of book history has created a field that if it is not openly hostile to gendered work is at best ambivalent about it. Taken out of its initial context and expanded beyond what either Tanselle or McGann initially imagined, this debate has helped to create a set of core values that inhibit the appropriate impact of work within women's book history that is actively being done and that has been done for decades.

I argue that a key reason why this particular bibliographic thread became canonical in book history when it did is its explicit disengagement from other forms of critical theory. Raven frames scholars who flocked to book history in the 1960s and 1970s as historically minded "refugees" from the wave of critical theory that was engulfing the academy (2018, 4). Critical theory became the dominant methodology that scholars used to make 
meaning from literary texts in the latter half of the twentieth century. In response, these scholars made a sanctuary of text, provenance, and material books. In the form of bibliography that has been canonized in book history, it is indeed true that bibliography has been largely impermeable to critical theory; as the rest of this section shows, not all bibliography practices this methodological distancing. But there is an unspoken wariness in the frequent characterization of historicity and theory as antithetical, an ideology that is not limited to Raven's backward gaze but explicitly and implicitly expressed by many scholars who took to bibliography and textual studies in this period. It is not all critical theory that was viewed askance; after all, it was work from Barthes and Foucault as part of linguistic structuralism and poststructuralism that prompted many of the discussions of authority in bibliography. It was critical theories that challenged long-held beliefs about aesthetic value and rewrote narratives of literary genealogy and greatness. This dissonance suggests that bibliography and book history were a haven not only for historically minded analysis, but also for work that was free from the messiness of what critical theory introduced to the academy: diversity of subject matter.

We can see this in what subjects these core scholars worked on and how this work has been positioned by contemporary book historians. The scholars that "fled" theory were largely working on white men. Tanselle's primary subject was Herman Melville; McKenzie's famous essay highlights Jacob Tonson and William Congreve; McGann worked on Lord Byron, Dante Rossetti, and William Blake. As only focusing on this category of writer, white men, became less common and open to critique more broadly in literary studies and history, the version of bibliography and book history that we cite and elevate as canon offered a haven of racial and gendered sameness. The impact of this narrative's values and tightly drawn boundaries are still widely and powerfully felt, not only in what journals intersectional book history scholarship appears in (it is rarely found in book history-focused journals, but instead in feminist journals like Women's Writing and specialized edited collections), but in the new directions proposed by the field's leaders.

One of the suggested shifts in book history is toward book studies, as proposed by Jonathan Rose (2001). Rose is somewhat anomalous in that he does not explicitly cite McKenzie and McGann; rather, he locates the origin of the field in the historical work of Darnton, Febvre, Martin, and Elizabeth Eisenstein (1979). Rose's term "book studies" correctly attempts to re-situate the name of the field around a culture, intersection, or discourse 
rather than a specific field (history), and it also helpfully looks forward rather than re-telling the past. As a product of its lineage, however, Rose's characterization draws the same boundary lines as discussions of social textual criticism, historical bibliography, and sociology of the text. That is, while Rose's term is arguably a better representation of the field, the divide between theory and object-oriented studies is maintained. He argues:

It is perfectly legitimate to ask how literature has shaped history and made revolutions, how it has socially constructed race, class, gender, and so on. But we cannot begin to answer any of these questions until we know how books (not texts) have been created, reproduced, disseminated and read, preserved and suppressed.

Rose advocates that the physical transmission of knowledge fundamentally matters and must be considered, but in doing so he also argues that issues such as race, class, and gender are secondary to the study of the book. Or, perhaps more accurately, he implies that books themselves cannot be gendered, raced, queered, or made products of class distinctions. By separating process from content, Rose reiterates the common, core thread of book history scholarship and illustrates how in this separation, critical engagements of race, class, gender, etc. are assigned to contents rather than materiality. The implication is that there is such a thing as objectivity, that it is possible to divorce ideology and identity from ourselves as well as those who created, reproduced, disseminated, read, preserved, and suppressed the objects we study. There is danger in this normative structuring of the field, as even if it is unintentional it not only works to obscure the complex cultural production of materiality but also allows practitioners to escape self-analysis and critical reviews of methodologies.

Book historians must grapple with this genderless and raceless inheritance, just as Amy E. Earhart argues such grappling must occur within digital humanities (2015). Despite McGann's presentation of his textual theory as a "universal condition", Michael K. Young argues that it "operates only within particular histories" (2006, 29); and, specifically, that "[t]hese political and social functions [. . .] are particular to an implicitly unraced society and politics" $(2006,29)$. Young's methodology includes critical race studies as he is working on black publishing in the United States, and he demonstrates how this transforms our textual categories. In a parallel moment in Ezell's work on editing women writers in England, she observes that, 
The challenges faced by the teams of editors producing the definitive multi-volume editions of the works of Mark Twain or Herman Melville, the layers upon layers of cross-checking with multiple sources and versions, were impressive. Given that I was working on early modern women writers for whom in many cases only a single text, either printed or handwritten, was known, such activities also seemed at one level remote and alien.

What Ezell and Young gesture toward is the limitations of conclusions and methods from bibliography. That scholars who do not work on white men in print often report feelings of "remoteness" and "alienness" should impact how the field is defined and suggest how to revise it to bring these important and diverse experiences closer to the conceptual center.

One way of addressing this gap is to collapse the perception of book history and critical theory as diametrically opposed. In fact, theoretical discourses focused on the book and historical narratives have been long lived. As Raven acknowledges, the history of the book has enjoyed sustained popularity partially because scholars from theoretical discourses like feminism have found its approaches useful and necessary $(2018,4)$. The reality of theoretical work is that it is often historical, not incidentally but by design. Theory builds on history to form its narratives. Within feminism, it is what Kate Eicchorn calls "a desire to take control of the present through a reorientation to the past" $(2013,8)$. Similar moves have been traced in critical race theory by scholars like Simon Gikandi (2015), Imtiaz H. Habib (2016), and Saidiya Hartman (1997). Many theoretical discourses have developed a subfield of book history, represented in pockets: books like Robert Fraser's Book History Through Postcolonial Eyes (2008); the University of Virginia's Rare Book School-sponsored 2017 conference on "Bibliography Among the Disciplines" that marked a push for a global book history; the London Rare Book School's 2017 class on "The Queer Book" taught by Brooke Palmieri; thriving fields of black bibliography and African American print culture recently explored at the University of Delaware's 2019 conference "Black Bibliographia: Print/Culture/Art". ${ }^{8}$ There is also a vibrant cohort of early career scholars who perform this work and ask hard questions in the ephemeral ways that academics debate, at confer-

8. See also Jackson 2010 for an important contribution to new work on African American print cultures. 
ences and on social media. Each discipline emphasizes that objectivity of interpretation is not a second step but woven into the work of the bibliographer and the book historian.

As an example, feminist textual editing provides an alternative bibliographical underpinning that renders both bibliography and its adaptation within book history pointedly gendered. Feminist textual criticism dates back to the McGann-Tanselle debates and continues in contemporary work on scholarly editing from Julia Flanders (1998), Amanda Gailey (2012), and Martha Nell Smith (2007). These editors and scholars have reconsidered the basics of editorial practice to avoid normalizing the voices they are attempting to bring to the scholarly community. It is practicing what Smith encourages: namely, to "take into account the 'messy' facts of authorship, production, and reception: race, class, gender, and sexuality" when developing an editorial apparatus (2007, 2). Smith and other feminist textual editors have offered thoughtful critiques of an "objective" editorial apparatus. They argue that editorial practice is inherently subjective and based on the ideology of both editor and reader. Neglecting this reality can reduce diverse experiences into a seemingly objective or scientific methodology that was not designed to accommodate difference. Being wary of the lure of objectivity is not tantamount to avoiding rigor or method. On the contrary, it is, as Smith argues, to imagine how rigor can be adapted based on "principled flexibility" $(2007,2)$. That is, editors can retain the "rigor and sharp discipline required of principled methodologies" while also exploring areas of subjectivity, underlying ideologies, and the importance of understanding initiatives for diversity more broadly (Sмітн 2007, 2).

Gendered philosophies are particularly useful where editors are asked to judge between textual discrepancies and philosophies about what kind of texts one should produce - be it the author-centered "pure" text from Bowers and Tanselle or the reader-focused texts that have grown in popularity over the last thirty years. In these moments, gendered philosophies can and should intervene in the "male editorial tradition", as Ann Thompson $(1997,85)$ argues in her approach to Shakespeare:

Editors of Shakespearean texts have always had to choose between possible readings, and it is arguable that a feminist editor might make a different set of choices. In the case of plays that survive in two or more early printed versions, editors have to choose which version they see as more "authoritative". This choice will depend on a number of factors including of course an argument about the provenance of each text, but 
an awareness of gender issues can contribute to such a choice in the present and help explain the reasons behind editorial decisions made in the past.

Thompson's work on Shakespeare grapples with an author who has been at the center of bibliographic scholarship for decades. She consequently sees her task as unraveling not only the different iterations of the text but problematic editorial apparatuses that could have framed the author or individual characters or plays through a male-focused ideology. Similarly, feminist book history involves not only the study of women and their work, but also unpacking the male bibliographic tradition that has rendered certain books and authors as marginal.

Thompson's reimagining of Shakespeare is concurrent with the work of a variety of feminist scholars - especially Brenda R. Silver (1991) and Katie King (1991) — as well with the work of other scholars friendly to feminist intervention, such as Morris Eaves (1994), Gerald MacLean (1997), and Jeffrey Masten (1997). Closely following McKenzie's articulation of the sociology of the text and its subsequent critiques, Silver and King forwarded an alternative editorial narrative that exploited the concept of a social text to interrogate gendered ideologies and perceptions. Working on Virginia Woolf, Silver studies how feminist editing has revealed to what extent we as editors construct the author, and how unstable our stable text is when we lay bare these ideologies. For her part, King argues that bibliography's shift from "the world in the text to the text in the world" allows feminist recovery to "[open] up enormous questions which explicitly challenge assumptions about literary value and implicitly challenge assumptions about the nature and ontology of the text" $(1991,96)$. King's construction of an alternative, feminine apparatus for approaching literary texts sits in the gap between the empirical and the abstract, taking a critical philosophy and from it imagining a systemic approach.

Thompson, Silver, and King represent the ways that feminist theories have uncovered the ideologies that govern seemingly neutral textual theories. By representing their work as interventionist, these editors have also uncovered the ways that editing is "a social act with political implications", as Eaves has characterized it $(1991,91)$. So, too, is the work of book history. These theories of textual studies intervene politically, arguing one cannot have an editorial theory without values and scholarly judgment informing its approach. Taken collectively, this discourse explores "the extent to which those cultural conditions [of textual production] are crosshatched by 
the complex articulation of class, gender, sexuality, and national or racial identity" (MacLean, 1997, 35).

When alternatives are paired with more mainstream editorial theory from Tanselle, McGann, and McKenzie, one is able to see to what extent the latter discourse is dependent on valuing white male authors for its methods and philosophical approaches. All three figures used the genderless, general language of masculine bibliography that became canonical in book history scholarship, whereas feminist textual theory explicitly identified itself as interventionist. The dichotomy of feminism as marginal and bibliography as mainstream, but implicitly male-centered, has gone unrevised. Feminist textual editing provides a foil for this implicitly male history that removes the veneer of objectivity and necessitates that editors articulate a transparent response to issues of diversity as much as they carefully construct philosophies of textual authority. No narrative of history is unbiased, and no material object comes forth from a space or process anesthetized of the cultural identities of its creators or modern practitioners. Indeed, as Tanselle himself wrote, "every effort to establish past events however disciplined by what are taken to be responsible ways of handling evidence - is a creative act, involving judgments at each step" $(1988,33)$. Book history as it currently defines itself grows from the creative judgment of bibliographers who worked on a narrow set of texts and subjects. No matter how transformative and illuminating their observations are, they cannot be universally applied to the realities, values, and contributions of texts and subjects that deviate from the white, male, print-focused norm. The issue is that the prominence of this central line of genderless and raceless bibliography translates to its suggestion as a universal standard in book history. At best, methods created only from one group of authors serve as inspiration or foundation for how to work on other subjects; at worst, these methods are barriers that create standards against which other authors and texts are disproportionately judged.

\section{Building a Feminist Bibliography}

A feminist bibliography revises the way that studies of the material book are practiced and conceptualized. For feminist book history to take hold within the broader field, it needs a framework upon which to graft and a name to give it force and organization. It needs feminist bibliography. We need a list from which to draw women founders that transform the masculine narrative of book history's origins and roots. Since these roots are in 
areas like historical and descriptive bibliography, it is within these spaces that I find a feminist history of the field.

Searching for a feminist bibliographic tradition led me to center first on bodies rather than objects. Specifically, I searched for women who worked within and around the history of the book through a query to the listserv for the Society for the History of Authorship, Reading and Publishing. ${ }^{9}$ This initial search yielded more than 90 names, some of which are relatively well known. One of our foundational books is Eisenstein's The Printing Press as an Agent of Change. Scholars working in the book trades rely on the work of Mary "Paul" Pollard, Maureen Bell, and Robin Myers. Marie Tremaine and Katharine F. Pantzer are honored with named fellowships from the bibliographical societies of Canada and America, respectively, for their foundational work. Tremaine, who worked at the Toronto Public Library, is remembered as the "doyenne of Canadian bibliographers". Her major publications include A Bibliography of Canadian Imprints (1952) and Arctic Bibliography (1953-1975), which are still the standard works in the field and represent a career of exhaustive and meticulous research. ${ }^{10}$ Pantzer's completion of the revised Short-Title Catalogue of Books Printed in England, Scotland, and Ireland (1976) while at the Houghton Library created an indispensable research tool for scholars of the Early Modern English book trade. She was the first woman to be awarded the Bibliographical Society's gold medal. ${ }^{11}$ Also among distinguished women bibliographers is Ruth Mortimer, curator of rare books at Smith College, first woman president of the Bibliographical Society of America and longtime editor of its Papers. Mortimer published catalogues of Harvard's incunabula in addition to having a storied career as a professor of book history.

Beyond this core sample of women, however, it became clear that the titles "bibliographer" and "book historian" were no longer correctly capturing what I found. These were masculinized terms that had been drawn to value a certain kind of scholar and a certain kind of labor. Bibliography as a

9. A number of the following women in bibliography and book history were suggested by Jessamy Carlson, Patrick Cates, Michelle Chesner, Elizabeth DeBold, Silvia Glick, Jacqui Grainger, Molly Hardy, Emiko Hastings, Laura Helton, Dennis C. Landis, Mary Lu McDonald, Philip Palmer, Christine Pawley, Sal Robinson, Erin Schreiner, Jill Shefrin, Deidre Stam, Christopher Walker, and Kurt Zimmerman.

10. As with most bibliographies, Tremaine's work has been supplemented and critiqued in the decades between now and its publication; see FLEMING (1999) and KenNedy (1992).

11. My thanks to Leslie Howsam for providing this information. 
discipline came of age in the early and mid-twentieth century, and women's participation dramatically changed as their access to education and scholarly spaces in the Western world shifted. Most of the male bibliographers cited in this article have doctoral degrees from elite universities including Cambridge, Oxford, Northwestern, and Yale. They received degrees and were appointed to professorships at a time when women were not even formally admitted to these universities. This changed in the 1960s and 1970s with the influence of second-wave feminism and the Civil Rights movement, which coincides with bibliography's evolution into book history and critical theory's challenging of long-held beliefs about literary greatness. Thus, the fleeing of historically minded "refugees" to book history takes on another layer of the shoring up of masculinized historical research in the face of an increasingly diversifying professoriate.

Before the 1970s, however, women were still contributing to the history of the book, and it is this earlier period that I focus on here. Many women were curators like Mortimer or cataloguers, indexers, archivists, and librarians. They did bibliography, but often were not identified as bibliographers professionally. My search thus became a search for women's bibliographic labor, a phrase I owe to Christine Nelson at the Morgan Library, because it resists relabeling women as bibliographers and eliding their ties to fields like librarianship. To label them all "bibliographers" would erase a gendered history of bibliographic labor.

Most women's bibliographic labor is found in libraries. As a feminized profession, librarianship has been historically undervalued since its formal creation in the mid-nineteenth century. Similar to nursing and teaching, librarianship was considered "appropriate" work for women because it was service-oriented (HARris 1992). Debates about women in librarianship were immediately sexist and long-lived. ${ }^{12}$ The gendering of the field can be found in the kind of work that women librarians perform, which is more likely to be in public rather than academic libraries (TAY LOR 1995, 102 and Weibel and Heim 1979, xiii). It is in how they are compensated, which is less well than their male-identified colleagues, and in the unevenness of their promotion ( $\mathrm{LYNCH}$ 1999). Adding to this feminization, and consequent devaluation, was professional gatekeeping. In the early twentieth century when Bowers and Greg were publishing in bibliography, librarians

12. For examples of debates in England, see Colem An (2014a and 2014b) and KerSLAKe (2006). For examples in America, see MAACK (1998), Hansen (2017), and Weibel and Heim (1979). For Canada, see Harris (1992) and Lorne (2012). 
had less formal training than literary doctorates, usually completing only a two-year program.

These factors contribute to the gerrymandering of women's bibliographic labor away from the core of book history scholarship, despite their performance of much of the same labor in a different context. Molly O'Hagan Hardy writes as much of Avis G. Clarke, cataloguer at the American Antiquarian Society. Clarke's output was staggering. She created thousands of cards of the American Antiquarian Society's holdings, and Hardy argues that the cards "write and rewrite the history of early American, Caribbean, Scottish, Irish, and English printing and all of the labors associated with it" (2016, n.p.). Hardy argues that Clarke's labor was not clerical but scholarly; she "writes and rewrites" the history of printing through cataloguing, which then shapes how researchers are prepared to think about these histories. This analysis positions Clarke as an actor, an interpretive force, in the history of the book in the United States and cataloguing as a crucial component of the field's labor.

There seems to be an Avis Clarke at every major literary institution in the Western world whose labor is, for one reason or another, undervalued. Greg and Pantzer are known for working on catalogues of English literature, but cataloguing work within a library is too easily regarded as simple reference work rather than true scholarly labor. This divide obscures the impact that such work has had on the creation of book history and the study of rare books. Among the legion of women cataloguers are Cora Edgerton Sanders of the William Andrews Clark Memorial Library (Powell 1950), Julia Pettee of the Union Theological Seminary (Walker and Copeland 2009), Mary Pollard at Trinity University (Benson and Fitzpatrick 2005), and Melanie Barber at Lambeth Palace Library (Brown 2013). These women, as Hardy argues with regard to Clarke, are agents in bibliographical history; they "write and rewrite" the history of the book and thus provide crucial interpretive labor. Considering as a whole their output makes a convincing case that the work of making books visible in catalogues and offering interpretive framing has facilitated every aspect of book history from the physical use of objects in the archive to the circulation of accurate metadata through standardized cataloguing in Machine-Readable Cataloging records (MARC), which, incidentally, was first programmed by a woman, Henriette Avram (RAther and Wiggins 1989). Essentially, without this labor, book history would not exist.

The list of women who fit this general description is vast, and cataloguing is only one aspect of how women have contributed to the history of the book. Another is through collection-building, which includes 
library administrators and private collectors. This thread of women's bibliographic labor is similarly gendered by professionalization and cultural gatekeeping. In the same time period before second wave feminism, women library administrators were rare. Joanne E. Passet argues that displaying the male gender trumped all other concerns when it came down to what made someone a good library administrator: "Even after describing men who were lacking in 'initiative and executive work', needful of 'friendly criticism', 'self-distrustful', and 'more or less nervous', directors would conclude: 'He ought to be at the head of his own library"' (1993, 397). Even if women administrators were a numerical minority, their contributions are still significant. They were responsible for building the collection, training and managing staff, and processing dizzying amounts of new material. Columbia University's Butler Library was staffed by a number of remarkable women such as Harriet Beardsley Prescott, head of the cataloguing department. Prescott's tenure included a marked increase in volumes in the library. Jane Siegel writes that "In 1889, when Harriet started working there, the Library contained just under 100,000 volumes; by her retirement in 1939, there were 1,400,000 volumes" (2018, n.p.). Elsewhere in New York, Belle da Costa Greene transformed the Pierpont Morgan Library from "a rich man's casually built collection into one which ranks with the greatest in the world" (Ardizzone 2007, 4-5). Greene was the library's director for more than two decades, and her documentation practices are built into its infrastructure. Christine Nelson, Drue Heinz Curator of Literary \& Historical Manuscripts, and Sal Robinson, Assistant Curator, report that they refer to Greene's handwritten accession books and card catalogues when locating volumes in the collection. In Washington D.C., the Folger Shakespeare Library boasts Eleanor "Molly" Pitcher who was, according to Elizabeth DeBold, "a seasoned purchaser and nobody's fool" (2018, n.p.). Pitcher was head of acquisitions, and during her career

the Folger succeeded in adding more than 19,000 Sixteenth and Seventeenth Century English titles to its shelves, 22,000 Continental imprints from the same two centuries, and numerous Eighteenth Century books. Considering that Mr. Folger's original bequest of rare books had numbered fewer than 7,000 titles and the Harmsworth purchase of 1938 fewer than 12,000 titles, the magnitude of this accomplishment is evident.

(Mason, Fowler, and Knachel 1969, 364)

Women's role in collection-building is also pointedly linked to feminist activism. Women not only shaped book history, but did so politi- 
cally, writing their point of view into the catalogues and scholarship they produced. Dorothy B. Porter, curator at what is now Howard University's Moorland-Spingarn Research Center, changed how library infrastructure handled black authors and their work. Laura E. Helton writes that Porter "decided to dismantle the tools she learned in library school and remake them to capaciously delineate blackness" $(2019,101)$. Porter rewrote the card catalogue and redefined how the Dewey Decimal System was applied to black literature. The foil in prestige and scope to Howard's collection of black literature was the Division of Negro Literature, History and Prints at the $135^{\text {th }}$ Street Branch of the New York Public Library. The division's first African-American librarian was Catherine Allen Latimer, who spent her career cataloguing the collection and working with the community alongside several other women of color including Nella Larsen (Roffm AN 2007). They worked with library head Ernestine Rose to build a collection that represented the vibrancy of the Harlem Renaissance (НоснMAN 2014). As head of the West End branch of the Boston Public Library, Fanny Goldstein created programming for immigrant communities that included Negro History Week, Jewish Music Month, Catholic Book Week, and Brotherhood Week (Sмiтн n.d.). She additionally built the secondlargest Judaica collection in the United States. Goldstein's attention to a diverse population of children readers was shared by many women librarians, notably Charlemae Hill Rollins, who was head of children's literature at a branch of the Chicago Public Library. Rollins worked at the George Cleveland Hall Branch Library under director Vivian G. Harsh when it opened in 1932 as the first library in a black neighborhood in Chicago. Confronting a list of children's literature that negatively portrayed black children, Rollins compiled We Build Together: A Reader's Guide to Negro Life and Literature for Elementary and High School Use (1967) as a more appropriate reading list. It was one of her many publications that sought to address systemic bias by using bibliography as activist resistance.

Women who were not librarians have also used collection-building to combat silence about women's history in the same activist vein. One remarkable collector was Miriam Young Holden, who amassed a collection in her New York City brownstone of more than 6,000 books on the history of women. Unable to find what they were looking for elsewhere, researchers like Gerda Lerner came to Holden's meticulously organized home where she allowed them access to her private collection. "In this library the history of women was a reality", Lerner writes. "The possibilities of comparative and interdisciplinary approaches were evident" $(1980,164)$. Holden's collecting was about purpose more than aesthetics, and her archive shows that she 
assiduously collected every pamphlet, book, and piece that she could find on women's history and experiences. Addressing the Hroswitha Club, a group of women book collectors, Holden said, "Please remember when you see my books that I do not have them because they are rare or because of their value. I collect them only because I hope they contain within them some significant records of women that will be meaningful to those who are seeking and using them" $(1960,4)$. When she died, she arranged for her collection to be donated to Princeton, where it sits in open stacks to be used by current students and researchers, continuing her legacy.

Holden's collecting and extensive self-education allowed her to advocate for systemic educational change. Similar to women librarians, she was not able to attend major universities or receive an advanced degree. She attended Simmons College but seems to have left after one year in $1914 .{ }^{13}$ Aware of this disparity, Holden spent decades alongside colleagues including Eugenia Leonard and Mary Beard petitioning universities to teach a single course on women's history. They "wrote proposals, curricula, bibliographies, and position papers; they nagged college presidents and alumnae trustees and, for the most part, failed to make a dent, yet they persisted" (Lerner 1980, 165). Their persistence did, eventually, pay off. Through a sustained effort with Radcliffe College faculty like Elizabeth Borden and Beard, her colleague-in-arms, Holden helped foster the Women's Archives and was instrumental in convincing Harriet Beecher Stowe's family to donate her papers. ${ }^{14}$ She was a National Consultant for the archive, which she and her colleagues believed was necessary to make the foundation for future curriculum. Beard wrote "the preparation of women to teach courses on women in history can only be tackled when the equipment for this preparation is on hand. Research will have to precede such training" (1944). Holden invariably agreed, writing:

The greatest benefit I have received from my own collection is self-education in the significance of what woman has been able to achieve in

13. Holden, as Miriam Young, is listed in the 1914 Simmons College yearbook Microcosm as a student "admitted to pursue irregular or partial programs"; see pages 105-6. She studied social work but did not receive a degree. My thanks to Sara A. Howard, Emma Sarconi, and Jason Wood for their assistance in researching this question.

14. See Box 1, Folder 50, Miriam Y. Holden Collection, Princeton Rare Books. Holden visits Stowe's family several times and writes letters to Radcliffe's administration to petition for a space for the library. 
long history as well as what she has not yet achieved. When books are put together with that end in view, they begin to say something, and I believe they can help guide the students to an attitude of mind that will help them to face the future.

Holden's activism confronted a gendered social norm that shaped every aspect of her life, including her interaction with the book world. It also confronted the norms of academia that worked to keep women out of male spaces and to delegitimize their histories by refusing to collect or teach them. Collection-building combats women's historical erasure, and other collectors including Lisa Unger Baskin, Anne Lyon Haight, and Marjorie Dana Barlow have used this method to similar effect. Barlow, Haight, Holden, and Greene were also members of Hroswitha Club, which Haight created with a dozen other women in 1944 because women collectors were not admitted to male spaces like Grolier Club.

As this overview indicates, women's history within book history is not only vast but also expands the space we can cite as the field's origins. A feminist approach knits a narrative of book history through librarianship, book collecting, and textual editing alongside the traditional space of bibliography. These choices make disciplinary sense: imagining the modern study of rare books without libraries and archives is next to impossible, nor is it sound to consider studying an object without an awareness of its provenance. While the increased number of women in academia has changed some of the dynamics presented in this narrative, others remain staunchly unchanged. The sedimentation of sexism still permeates the field, which no doubt contributes to the preservation of genderless bibliography as the core of book history's values. Pointedly feminist work is often met with opposition, and even this piece has received its fair share as it progressed through conferences and the peer review process. A feminist book history might also combat women's continued marginalization by writing their labor back into our histories and using the epistemological power of bibliography as activism rather than a conservative influence.

In sum, feminist book history has a rich past on which to draw to reimagine the dynamics of our field and to give scaffolding to current feminist scholarship. Scholars including Maureen Bell, Margaret J.M. Ezell, Leslie Howsam, Michelle Levy, Lisa Maruca, Helen Smith, and Sarah Werner provide theoretical considerations about women's book history, and the Women in Book History Bibliography gives a deep citational pool from which to draw. Each of these authors should appear with regularity in companions 
and other introductory books (and not only as the editors, which three of them are). Secondly, we can use the critiques of feminist textual editors like Julia Flanders, Amanda Gailey, Katie King, Brenda R. Silver, Martha Nell Smith, and Ann Thompson to challenge the history of textual editing that has been canonized within book history and instead introduce explicitly feminist and political language to our foundations. Third, we should expand our definitions of bibliography and book history to explicitly include the work of librarians, cataloguers, indexers, and archivists who have made the modern study of rare books possible and whose hands "write and rewrite" the history of books. These accounts challenge disciplinary elitism and sexism that have left librarianship on the feminized margins of book history. Lastly, we should look outside the academy for women book collectors like Marjorie Dana Barlow, Lisa Unger Baskin, Anne Lyon Haight, and Miriam Young Holden, whose building of bibliographical narratives has formed the study of women's history and literature.

The conceptual work of feminist book history is still in flux, and if the pulse of a discourse can be taken by the appearance of conference panels and scholarly work in progress, this field will soon tip into a broader discussion. This means that now is the moment when feminist book history can be formed as a field that is more inclusive than exclusive. Most of the conceptual work on feminist book history, my own included, is from scholars working on white women in England. It is essential that feminist book history make connections with the other pockets of diverse book history scholarship lest we repeat our key faults. It is not enough to simply be a white women's book history in England. It is only when book history, as a discourse, begins to create space that allows us to value the incredible breadth of studies of the material book that we can start to adapt to our own diversity. If we are able to accomplish this, studies of the material book will be the better for it.

Cal Poly Pomona

\section{Works Cited}

Аввотт, Craig S., and William Proctor Williams, eds. 2009. An Introduction to Bibliographical and Textual Studies. 4th ed. New York: Modern Language Association.

Adams, Thomas R. and Nicolas Barker. 2001. "A New Model for the Study of the Book". In A Potencie of Life: Books in Society. The Clark Lectures, 1986-1987, 5-43. London; New Castle: British Library; Oak Knoll Press.

Ardizzone, Heidi. 2007. An Illuminated Life: Belle Da Costa Greene's Journey from

Prejudice to Privilege. New York and London: W. W. Norton and Company. 
Barnard, John, D. F. McKenzie, David McKitterick, and I. R. Willison, eds. 1999-2019. The Cambridge History of the Book in Britain. 7 vols. Cambridge: Cambridge University Press.

Barthes, Roland. 1977. "Death of the Author". In Image, Music, Text, translated by Stephen Heath, 142-8. New York: Hill and Wang.

Beard, Mary Ritter. 1944. "Letter to Miriam Holden”. Miriam Y. Holden Collection, Princeton Rare Books.

Bell, Maureen. 2014. "Women and the Production of Texts: The Impact of the History of the Book". In The Book Trade in Early Modern England: Practices, Perceptions, Connections, edited by John Hin ks and Victoria Gardiner, 107-31. London: The British Library Publishing Division.

Benson, Charles and Siobhan Fitzpatrick, eds. 2005. That Woman - Studies in Irish Bibliography: A Festschrift for Mary 'Paul' Pollard. Dublin: The Lilliput Press, 2005.

Bowers, Fredson. 1949. Principles of Bibliographic Description. Princeton: Princeton University Press.

Brown, Clare. 2013. "Melanie Barber M.B.E., B.A., M.A., F.S.A. (1943-2012)". Archives and Records 34.2: 263-5.

Bruce, Lorne. 2012. "Professionalization, Gender, and Librarianship in Ontario, 1920-75". Library Eु Information History 28.2: 117-34.

Coleman, Sterling Joseph Jr. 2014a. “'No Room for Her Here!' The Numerical Feminization of Public Librarianship in England, 1871-1914”. Libraries $\mathcal{E}$ Culture 30.2: 90-109.

2014b. "Eminently Suited to Girls and Women': The Numerical Feminization of Public Librarianship in England 1914-31”. Libraries $\mathcal{E}$ Information History 30.3: 195-209.

DeBold, Elizabeth. 2018. "Under Cover: Forged Bindings on Display at the Folger". The Collation: Research and Exploration at the Folger. https://collation.folger. edu/2018/07/forged-bindings/.

Dunn, Marilyn. 2013. "Convent Creativity". In The Ashgate Research Companion to Women and Gender in Early Modern Europe, edited by Allyson M. Posk A, Jane Couchman, and Katherine A. McIver, 53-74. New York: Routledge.

Earhart, Amy E. 2015. Traces of the Old, Uses of the New: The Emergence of Digital Literary Studies. Ann Arbor: University of Michigan Press.

Eaves, Morris. 1994. “'Why Don't They Leave It Alone?': Speculations on the Authority of the Audience in Editorial Theory". In Cultural Artifacts and the Production of Meaning: The Page, the Images, and the Body, edited by Margaret J.M. EzelL and Katherine O'Brien O'Keeffe, 85-100. Ann Arbor: University of Michigan Press.

Eich horn, Kate. 2013. The Archival Turn in Feminism: Outrage in Order. Philadelphia: American Literatures Initiatives.

Eliot, Simon, and Jonathan Rose, eds. 2009. A Companion to the History of the Book. New York: Wiley-Blackwell. 
Ezell, Margaret J.M. 2010. "Editing Early Modern Women's Manuscripts: Theory, Electronic Editions, and the Accidental Copy-Text”. Literature Compass 7.2: 102-9.

Finkelstein, David, and Alistair McCleery, eds. 2006. The Book History Reader. 2nd ed. London: Routledge.

2012. Introduction to Book History. 2nd ed. New York: Routledge.

FLAnders, Julia. 1998. "The Body Encoded: Questions of Gender and the Electronic Text". In Electronic Text: Investigations in Method and Theory, edited by Kathryn Sutherland. Oxford: Clarendon Press.

Fleming, Patricia Lockhart. 1999. Early Canadian Printing: A Supplement to Marie Tremaine's "A Bibliography of Canadian Imprints, 1751-1800". Toronto: University of Toronto Press.

Foucault, Michel. 1977. "What Is an Author?” In Language, Counter-Memory, Practice, edited by Donald F. Bouchard, translated by Donald F. Bouchard and Sherry Simon, 113-38. Ithaca and New York: Cornell University Press.

Fraser, Robert. 2008. Book History Through Postcolonial Eyes: Rewriting the Script. New York: Routledge.

GAiley, Amanda. 2012. "Cold War Legacies in Digital Editing”. Textual Cultures 7.1: 5-17.

Gallon, Kim. 2016. "Making a Case for the Black Digital Humanities". In Debates in the Digital Humanities. Minneapolis: University of Minnesota Press.

Gik Andi, Simon. 2015. "Rethinking the Archive of Enslavement". Early American Literature 50.1: 81-102. https://doi.org/doi:10.1353/eal.2015.0020.

Greeth a M, D. C. 1989. "Textual and Literary Theory: Redrawing the Matrix". Studies in Bibliography 42: 1-24.

1994. Textual Criticism: An Introduction. New York and London: Garland Publishing.

НАвів, Imtiaz H. 2016. Black Lives in the English Archives 1500-1677: Imprints of the Invisible. Reprint. New York: Routledge.

Hall, David D., ed. 2014. A History of the Book in America. 5 vols. Chapel Hill: The University of North Carolina Press.

Hansen, Debra Gold. 2017. "Library Wars: The Making of Librarianship at the Los Angeles Public Library, 1890-1910”. Libraries: Culture, History, and Society 1.1: 97-125.

Hardy, Molly O'Hagan. 2016. "'Black Printers' on White Cards: Information Architecture in the Data Structures of the Early American Book Trades". In Debates in the Digital Humanities, edited by Matthew K. Gold and Lauren F. KLEIN, n.p. Minneapolis: University of Minnesota Press. https://dhdebates.gc.cuny.edu/read/ untitled/section/3c4a647f-8f61-48b6-ab41-5d6e765ac70f\#ch31

Hall, Kim F. 1995. Things of Darkness: Economies of Race and Gender in Early Modern England. Ithaca: Cornell University Press.

Hartman, Saidiya V. 1997. Scenes of Subjection: Terror, Slavery, and Self-Making in Nineteenth-Century America. Oxford and New York: Oxford University Press. 
Helton, Laura E. 2019. “On Decimals, Catalogs, and Racial Imaginaries of Reading”. PMLA 134.1: 99-120.

Hochman, Barbara. 2014. "Investing in Literature: Ernestine Rose and the Harlem Branch Public Library of the 1920s". Legacy 31.1: 93-112.

Holden, Miriam Y. 1951. "Letter to Elizabeth Borden". Miriam Y. Holden Collection, Princeton Rare Books.

1960. "Address to the Hroswitha Club". In Hroswitha Club Meeting. New York, Privately Printed, 1-15.

Howsam, Leslie. 1998. "In My View: Women and Book History". SHARP News 7.4: $1-2$.

2006. Old Books and New Histories: An Orientation to Studies in Book and Print Culture. Toronto: University of Toronto Press.

- ed. 2014. The Cambridge Companion to the History of the Book. Cambridge: Cambridge University Press.

Jackson, Leon. 2010. "The Talking Book and the Talking Book Historian: African American Cultures of Print — The State of the Discipline". Book History 13: 251308. https://doi.org/10.1353/bh.2010.0014.

Kennedy, Patricia. 1992. "What Marie Tremaine Did Not Find: An Exploration of Archival Back Rooms". Papers of the Bibliographical Society of Canada/Cahiers de La Société Bibliographique du Canada 30.1: 27-51.

Kerslake, Evelyn. 2006. "The Feminisation of Librarianship: The Writings of Margaret Reed". In The Cambridge History of Libraries in Britain and Ireland, edited by Alistair Black and Peter Hoare, 548-55. Cambridge: Cambridge University Press.

KING, Katie. 1991. "Bibliography and a Feminist Apparatus of Literary Production". Text 5: 91-103.

Lerner, Gerda. 1980. "Miriam Holden - In Remembrance and Friendship". The Princeton University Library Chronicle 41.2: 164-8.

Levy, Michelle. 2014. "Do Women Have a Book History?" Studies in Romanticism 53.3: 297-317.

Levy, Michelle, and Tom Mole, eds. 2014. The Broadview Reader in Book History. New York: Broadview.

2017. The Broadview Introduction to Book History. New York: Broadview.

Lynch, Mary Jo. 1999. "Library Directors: Gender and Salary". American Library Association. http://www.ala.org/tools/research/librarystaffstats/diversity/libdirectors.

MaAck, Mary Niles. 1998. "Gender, Culture, and the Transformation of American Librarianship, 1890- 1920”. Libraries Eु Culture 33.1: 51-61.

MacLean, Gerald. 1997. "What's Class Got to Do with It?" In The Margins of the Text, edited by D.C. Greet ha m, 25-43. Ann Arbor: University of Michigan Press. Maruca, Lisa. 2007. The Work of Print: Authorship and the English Text Trades, 16601760. Seattle: University of Washington Press. 
Mason, Dorothy E., Elaine Fow ler, and Philip Knachel. 1969. "The Folger Shakespeare Library in Washington, D. C.: A Brief History". Records of the Columbia Historical Society, Washington, D.C. 69/70: 346-70.

Masten, Jeffrey. 1997. Textual Intercourse: Collaboration, Authorship, and Sexualities in Renaissance Drama. Cambridge Studies in Renaissance Literature and Culture. Cambridge: Cambridge University Press.

McDoweln, Paula. 1998. The Women of Grub Street: Press, Politics, and Gender in the London Literary Marketplace, 1678-1730. Oxford, New York: Clarendon Press.

McGann, Jerome. 1983. A Critique of Modern Textual Criticism. Chicago: University of Chicago Press.

1985. The Romantic Ideology: A Critical Investigation. Chicago: University Of Chicago Press.

McKenzie, D. F. 1999. Bibliography and the Sociology of Texts. Cambridge: Cambridge University Press.

Onyek a. 2013. Blackamoores: Africans in Tudor England, Their Presence, Status and Origins. London: Narrative Eye Ltd.

Passet, Joanne E. 1993. "Men in a Feminized Profession: The Male Librarian, 18871921". Libraries E3 Culture 28.4: 385-402.

Powell, Lawrence Clark. 1950. "From Private Collection to Public Institution: The William Andrews Clark Memorial Library". The Library Quarterly: Information, Community, Policy 20.2: 101-8.

Rather, Lucia J. and Beacher Wiggins. 1989. "Mother Avram's Remarkable Contribution': Henriette D. Avram”. American Libraries 20 (9): 855-61.

Raven, James. 2018. What Is the History of the Book? Cambridge: Polity Press.

Roffman, Karin. 2007. "Nella Larsen, Librarian at 135th Street". Modern Fiction Studies 53.4: 752-87.

Rollins, Charlemae Hill. 1967. We Build Together: A Reader's Guide to Negro Life and Literature for Elementary and High School Use. Champaign, Ill.: National Council of Teachers of English.

Rose, Jonathan. 2001. "From Book History to Book Studies". https://printinghistory. org/awards/society-history-authorship-reading-publishing-sharp/.

Siegel, Jane. 2018. "Harriet Beardslee Prescott (1866-1958)". Blog, Women in the Stacks and Other Aspects of Columbia University Library History. https://womeninthestacks.wordpress.com/.

Silver, Brenda. 1991. "Textual Criticism as Feminist Practice: Or, Who's Afraid of Virginia Woolf Part II”. In Representing Modernist Texts: Editing as Interpretation, edited by George Bornstein, 193-222. Ann Arbor: University of Michigan Press.

Sмiтн, Helen. 2012. "Grossly Material Things": Women and Book Production in Early Modern England. Oxford: Oxford University Press.

Sмiтн, Martha Nell. 2007. "The Human Touch Software of the Highest Order: Revisiting Editing as Interpretation”. Textual Cultures 1.1: 1-15.

Sмiтн, Helen. n.d. "Fanny Goldstein (1895-1961)". In Jewish Women's Archive Encyclopedia. https://jwa.org/encyclopedia/article/goldstein-fanny. 
Suarez, Michael F., and H.R. Woudhuysen, eds. 2010. The Oxford Companion to the Book. Oxford: Oxford University Press. , eds. 2013. The Book: A Global History. Oxford: Oxford University Press.

Tanselle, G. Thomas. 1971. "Textual Study and Literary Judgment". The Papers of the Bibliographical Society of America 65.2: 109-22.

- 1988. "Bibliographical History as a Field of Study". Studies in Bibliography 41: $33-63$.

TAYlor, Julia. 1995. "Left on the Shelf? The Issues and Challenges Facing Women Employed in Libraries from the Late Nineteenth Century to the 1950s". Library History 11.1: 96-107.

Thompson, Ann. 1997. "Feminist Theory and the Editing of Shakespeare: The Taming of the Shrew Revisited". In The Margins of the Text, edited by D.C. Greeth a m, 83-104. Ann Arbor: University of Michigan Press.

Walker, Christopher and Ann Copeland. 2009. "The Eye Prophetic: Julia Pettee". Libraries $\mathbb{E}$ the Cultural Record, Women Pioneers in the Information Sciences Part I, 1900-1950, 44.2: 162-82.

Weibes, Kathleen and Kathleen M. Heim, eds. 1979. The Role of Women in Librarianship, 1876-1976: The Entry, Advancement, and Struggle for Equalization in One Profession. Phoenix: The Oryx Press.

Werner, Sarah. 2018. "Weaving a Feminist Book History”. 1-8. https://sarahwerner. net/blog/2018/03/weaving-a-feminist-book-history/.

Young, John K. 2006. Black Writers, White Publishers: Marketplace Politics in Twentieth-Century African-American Literature. Oxford: University of Mississippi Press. 